\title{
Investigating the Implementation of English- Huffaz Program For Preschools
}

\author{
Ali, Z
}

\begin{abstract}
The study explores the implementation of a program namely English-Huffaz among preschoolers in their early years of education. It is a program that introduces the memorization of selected verses of the al Qur'an besides promoting the learning of English language among preschoolers that are from four (4) to six (6) years old. The study that employs qualitative data inquiry; in particular semi-structured interviews, gathers information from two (2) teachers pertaining to the implementation of teaching hafazan and English in one of the preschools in the district of Pahang, East Coast of Malaysia. Seven (7) themes emerge after data are analyzed employing inductive analysis. Findings that are obtained from the study are significant especially to Muslim parents who have the intention to prepare their children for the latter formative years of education; both for the needs of herenow and hereafter
\end{abstract}

Keywords: hafazan; English skills; preschools

\section{INTRODUCTION}

It has become a trend for Muslim parents in Malaysia to send their children at Islamic preschools as the latter can start learning the hijaiyah, then read short verses of al-Quran and finally make progress in memorizing the verses they read. Despite obtaining the knowledge of the hereafter, the knowledge of herenow as in acquiring language skills, is equally important in becoming a holistic young Muslim. Moreover, the former Deputy Prime Minister; Datuk Seri Dr. Ahmad Zahid Hamidi asserts that the Huffaz (memorizer of al Qur'an) need not only memorize the verses in the Holy Book, they also need to become professionals as they, can eventually be engineers, doctors and pilots, or even the Minister of Defense or Minister of Home Affairs (1). Dealing with the teaching and learning of English, the study that explores branded Islamic Montessori - The Brainy Bunch, found that the acquisition of the language in the preschools enable the preschoolers to become dynamic young Muslims whom are able to converse fluently in English as well as proficient in other language skills $(2,3)$

With this in mind, the goal of the present study is twofold. It explores the implementation of English-Huffaz Program in one of the Islamic preschools in the East Coast of Malaysia with regards to both; the running of hafazan curriculum and the teaching and learning of English among preschoolers that are from four (4) to six (6) years old. Nevertheless, it is necessary here to clarify exactly what is meant by Huffaz and hafazan in this paper. The term Huffaz refers to the servants; that is people who memorize the word of Allah or verses of the al Qur'an. In the current study, the Huffaz program that is investigated concerns with

Revised Manuscript Received on April 19, 2019.

Ali, Zuraina, Department of Modern Languages \& Human Sciences, University Malaysia Pahang, 26600 Pekan, Pahang, Malaysia. identifying the methods that are employed by the teachers in assisting preschoolers to memorize the selected verses of the al Qur'an. In addition hafazan refers to keeping and preserving the words (in Holy Book; al Qur'an) of Allāh. While the definition of English Program relates to identifying the skills that are taught to the preschoolers. Specifically, it investigates the pedagogy that is employed prior to conducting the subject in the selected kindergarten.

\section{METHODOLOGY}

\section{Research Design}

The current study employs qualitative research design in collecting its data. This is due to the intention of the researcher in identifying the teachers' views on the implementation of English-Huffaz Program. Moreover, the research design relies primarily on human perceptions and understanding (4). In the current study, the researcher attempts to understand the implementation of EnglishHuffaz Program that is implemented in Kindergarten Y (a pseudonym); a private Islamic preschool, through a qualitative data inquiry.

\section{Samples of the study}

Purposive sampling is employed in the current study. Two (2) teachers are identified to be interviewed due to they demonstrate these characteristics: have more than three (3) years of teaching experiences, teach English and hafazan to the students, available during the time of the interview and are trained with the preschools' curriculum. The reason of selecting them is also due to they are more familiar with their students compared to other teachers that are teaching in the kindergarten. As a case in point, during the interview, the two (2) teachers called a few preschoolers to demonstrate their abilities in memorizing selected verses of the Holy Qur'an besides testing one of the preschool's ability; age four (4), on his ability to communicate with the researcher in English.

\section{Data Collection}

The data is collected using semi-structured interviews. It is employed since the instrument is able to explore the views, experiences and beliefs of the interviewees (5). In the current study, the data collection methods are adapted from the procedures that are developed by DeJonckheere (6). Following the procedures, the researcher ensure the participants' ability in answering the interview items so as to 
provide the finest information besides considering their availability prior to the time the interview is conducted. Interview guide is also formulated as it serves as a guide consisting of follow-up and probing questions to be asked to the interviewees. Memoing and reflection take place at a reflects the content of the interviews and simultaneously makes notes about what she learns from the data.

\section{Data Analysis}

The Inductive Analysis by Harrell and Bradley (7) is employed to analyze the data of the current study. It requires the researcher to find words that are most commonly used prior to reading the transcripts. Also, it requires her to read the interview data line-by-line in relation to identifying relevant themes that may emerge from the data. In reporting the findings, verbatim reporting is conducted in that exact words that are uttered by the respondents are written in relation to the questions being asked during the interview sessions. Also, pseudonyms; Teacher 1 and Teacher 2, are written to identify the respondents in the current study.

\section{RESULTS OF THE STUDY}

This section discusses the results and findings of the current study. Findings are presented according to themes that are formulated by the researcher upon reading the transcript of the interviews. To recapitulate, a single research question is developed in that it gauges the implementation of English-Huffaz program that is adopted in Kindergarten $\mathrm{Y}$. The themes that are formulated after analyzing the transcripts are discussed in the proceeding discussions.

\section{Teaching of Islam}

The concept of English- Huffaz based program as it is informed by Teacher 1 starts off with teaching preschoolers the teaching of Islam. The preschoolers are taught adab (manners), regulations and other aspects that teach them to be discipline. According to her, it is important to teach the preschoolers $a d a b$ in the very beginning since they will be implementing it not only in school but also outside class. In fact, the preschoolers will behave according to what is thought to them when they are with their friends, teachers and families. Teacher 2 makes this remarks:

When (pre-schoolers) meet with friends, parents and society, (pre-schoolers) will know adab (manners) before entering the house - they should greet. When meeting smiling faces

For Teacher 1, she asserts that the teaching of Islam begins with teaching students to perform prayers (solah).

Normally (class activity) is done in the morning, after mass gathering. That is before the preschoolers take their breakfast. For new students who registered in the kindergarten, teachers will focus on reading (recitations of du' $a$ and selected verses of the Holy Quran) when they perform solah. At least, students are expected to gain basic knowledge of prayers; for example, rakaat (of prayers) and prayer time although the students still do not memorize the words (verses in prayers). very later stage and at this stage in that the researcher friends, (they need to) shake hands, say goodbye and give

\section{After morning assembly is for hafazan}

According to Teacher 1, the hafazan is conducted every morning. Precisely, hafazan is conducted right after students' morning assembly. Since the surah that they memorize is recited during prayers, preschoolers are required to begin the hafazan by first reciting the niyyah (prayers intention). Then, they are required to recall the selected verses of the al Qur'an in mass while the teachers listen to their recitations. Usually the recitation starts off with requiring preschoolers to recite the $d o$ ' $a$ for prayers, recite surah al Fatihah and later the actual hafazan or recalling of the selected verses of the al Qur'an. Interestingly, they are required to recite-aloud the verses to ensure junior students; ages four (4) to five (5); are able to follow the recitation of their seniors of six (6) years old. At time, the junior preschoolers are able to acquire and eventually memorize the verses as well. In this regard, Teacher 2 relays her experiences:

The activity started at $8.45 \mathrm{am}$ until at least 9.20am. Usually, the recitations (i.e. recall of the selected verses of the al Qur'an) are done in mass and the activity starts with reciting niyyah, Iftitah, Surah Al-Fatihah and so on. We (teachers) will encourage pre-schoolers to read aloud so junior pre-schoolers will listen to their seniors. Indirectly, we noticed that some of the junior pre-schoolers will be able to memorize not only Ifititah but also a few verses of the al Qur'an that their seniors memorized.

Further, Teacher 1 asserts the verses of the al Qur'an that are assigned to the pre-schoolers:

... among the verses are al-Fatihah, the three (3) Quls, alMasad, al-Kafirun.

However, for this year, as it is claimed by Teacher 1, the verses; al Mulk and Yaasin, are added to pre-schoolers' hafazan. She answers:

... for (pre-schoolers) who are 5 years old, beginning this year, (pre-schoolers)begin memorizing surah of Al-Mulk as an additional surah. For now, (pre-schoolers have memorized) verses 4 and 5 of the surah while verse 1 to 10 for surah Yaasin.

In addition, Teacher 2 finds that hafazan is more effective when it is carried out in mass. The preschoolers seem to memorise the selected verses of the Holy Quran better when they are able to listen to others reciting at the same time. The method is also found to be effective compared to requiring parents to help their children to memorise the verses when they are at home. In explaining this, Teacher 1 shares her experiences of trying the various methods of helping the preschoolers for the hafazan of the latter. Teacher 1 comments:

In my opinion massive recitation slots are conducted to preschoolers since the method is faster compared to individual recitation. We've also tried asking parents to test their children's reciting the verses but it was not successful. So, massive recitation slots in the morning gathering is more effective since everyone (i.e. preschooler) is able to listen to one another recitation of the selected verses of the Holy Quran. 


\section{Retention test enhances students' memorization}

To gauge the students' ability in memorizing the selected verses, they are tested with retention test. A one-to-one testing in relation to checking the students' ability is conducted by the teachers. Both, preschoolers and parents are able to see the achievement reports of the former so as to monitor their progress in memorizing the verses. This is explained by Teacher 2:

One-to-one testing is done to test the memorization of the students. Annually in students' progress reports, they can see their children's achievements. The verse that they memorized will be recorded in the report. For example, surah Yaasin ayat 1 and so on. From there (i.e. from the reports), parents can see (the achievement of their children).

The experiences of conducting retention test by Teacher 1 are akin to Teacher 2. She believes that preschoolers are able to memorize the selected verses of the Holy Qur'an when they read the verses repeatedly on daily basis. The children's achievement that is recorded in the report card provides parents with the progress of their children.

Researcher: Is the test retention test conducted individually?

Teacher: Yes. Retention test is conducted to individual student. In the students' report cards, parents can know their children's' achievement. For example, in the report card...let say for Surah Yaasin it will be remarked from what verse to what verse do they children have to memorize the assigned verses.

Researcher: I see.. Meaning, if the student memorize a lot (of the verse) they will get a high score (in achievement).. so this retention is conducted in front of the teacher?

Teacher: Right. And from the report cards, parents can see the marks (of their children).

Researcher: Are students assigned routine tasks with parents ...mmm.. For example - memorizing surah al Mulk with their mothers?

Teacher: We've suggested the method to parents but it seems that it is not easy to have that kind of collaboration since they are busy (with daily tasks). Surprisingly, we got feedback from parents who said that their child is able to read the sura of Al-Mulk when at home. So the method that is used now to repeat reciting the verses on daily basis. Soon the children will be able to memorize the selected verses assigned to them. This retention test is conducted after they sing 'Negaraku'.

\section{Homework to support the learning of English}

To support the learning of English, homeworks are assigned to the preschoolers. They need to do homeworks with the help of their parents. The parents are usually informed of the homeworks that are assigned to their children. Thus far, the teachers receive cooperation from the parents in carrying the task. The excerpt below illustrates Teacher 1 experiences in giving homeworks to her preschoolers:

Teacher: Yes, they are given homework and will bring back the necessary books.

Researcher: What about parents? Will they be notified?

Teacher: Yes, parents will be told to monitor and require their children to complete the homework ... and parents give good cooperation
Researcher: How long do you give the duration for preschoolers to complete their homework?

Teacher: It depends on the situation, some need to be sent on the next day or some two (2) days later. But there are also those who did not do their homework while other complete theirs much earlier

Teacher 2 agrees with the statements that is made by Teachers 1 . In assigning homeworks to the preschoolers, she believes that the roles of parents are crucial in making sure that the assigned tasks are completed by their children. Teacher 2 relays her views on this matter:

parents play a role to teach their children at home ... and they need to cooperate with teachers. If this is done, surely it will not cause problems. In sha Allah everything runs smoothly. Parents and teachers should share together the task of educating the preschoolers... anything that is taught in school, as parents they need to ask what their children learn at home... the role of parents is to "attract" children to learn. Sometimes, some parents think that only teachers should teach their children. But they need to remember that they need to play their roles as well to educate their children. If not ... sometimes ... if their children did not do well in school ... misunderstandings may arise between parents and teachers. So we do not want this situation to happen.

\section{Learning English through basic class instructions}

The learning of English among the preschoolers especially for those in Year 4 and Year 5, generally are through introducing basic class instructions. In class, the teachers would instruct preschoolers to perform tasks and indirectly the latter learn English using this approach. Teacher 1 shares her experience in teaching the preschoolers the basic command of English as shown in this excerpt:

As an example, before going out of class, the teacher give $a$ "line up" command by ringing the bell, and the student would make a line when they hear the instructions and did not run out of the classroom just like that. Basic use of English; for example when they ask for permission and other command can also help them to be more discipline and also show good manners. But indirectly, they learn the English ... although very basic. Like the use of English words in giving them instructions during assembly ... for example when we say "hands up", "hands down", "please be quiet", "make one straight line" ... So, when they hear these English terms, they understand and follow. That shows that they 'pick-up' basic instructions in English.

Listening skills is acquired through listening to Islamic songs

Listening skills is one the language skills that is taught to the preschoolers. Currently, the teachers are in the process of recording some Islamic songs despite using the Smart Reader modules for listening activities. Teacher 1 says:

Teacher: ... they are more likely to listen to the songs in English that are based on the book 'Smart Reader'.

Researcher: Are the English songs Islamic? 
Teacher: We are still in the process of recording the Islamic songs but we do have some Islamic songs that we (teachers) composed together.

Teacher 2 adds that listening skills can indirectly be obtained by watching (and at the same time listening) to the video in YouTube. She expresses her views as demonstrated in the excerpt:

Researcher: Where did you get the source of the video for English class activity? And what is the duration of the watch usually?

Teacher: Mostly from YouTube and will be saved in one pen drive. Students will watch the video after their morning assembly every Wednesday... Every week Wednesday is for co-curricular activity ... watching video is on that day as well ... we provide 30 minutes just like the daily schedule that is provided for every (normal) subject.

\section{Use of in-house reading and writing modules}

Kindergarten $\mathrm{Y}$ uses its in-house modules for reading and writing for pre-schoolers according to their years of schooling i.e. from Year Six, Year Five and Year Four. Nevertheless, more emphasis on reading is given to preschoolers in Year Four due to they are still new in their ability to gain the skill. Teacher 2 remarks:

For Year Six they have no problem in writing because they have the basic and are able to read and write. We currently use the modules that we developed on our own. But for Year 4 students, we will emphasize the Reading process first ... with the letter recognition methods such as 'A' for apple, 'B' for bear and 'C' for Cat'. So they learn by referring to the pictures and pronounce the words.

Since classes end at noon, only 30 minutes are provided for each English skill and other subjects. Therefore, teachers need to be plan the activity they will conduct in the class on a particular day. She stated:

Researcher: What is the learning time or the preschoolers' schedules like on daily basis ... I mean as far as a particular subject is concerned ... Is it like 30 minutes for English and 30 minutes for Malay or perhaps there are other schedules?

Teacher: Yes, right. Their daily schedule starts at 8:45am after they have their morning assembly ... then at 9:20am, prayers... they perform Dhuha (forenoon) prayers ...at 9:20am until 9:40am is for their breakfast. From 9:40am until 10:10am is the first subject follows by three (3) more subjects after that. In short, each subject is assigned for 30 minutes.

\section{DISCUSSION AND CONCLUSION}

In this study, the implementation of English-Huffaz Program has produced seven (7) themes. Concerning Huffaz program; in particular hafazan, three (3) themes are found 'Teaching of Islam', 'After morning assembly is for hafazan' and 'Retention test enhances students' memorization' while four (4) themes are produced in the teaching and learning of English - 'Homework to support the learning of English', 'Listening skills is acquired through listening to Islamic songs 'Learning English through basic class instructions' and 'Use of in-house reading and writing modules'.

This finding is consistent with a study that found that hafazan is the curriculum that is commonly integrated in the Islamic Montessori curriculum (2, 3). Their study showed that hafazan is introduced to the preschoolers relevant to their ages, together with introducing other Islamic studies plan i.e. Adaab \& Akhlaq Seerah, Tareekh and Arabic. Nonetheless, the advancement of technology may assist the memorization of the selected verses in the al Qur'an among the preschools. The use of assistive technology or humanoid robot enabled young learners; primary school students in Malaysia, to memorize the verses since it integrated repetitive motions in praying and memorizing the verses from the al Qur'an (8). The study found that robot Nao (humanoid) would be able to help children in memorizing short daily prayers selected from the al Qur'an. The fact that the verses are repeated when playing the device may enhance the children's ability in memorizing the verses. However, it was a challenge for teachers when robot Nao (humanoid) stood stationary after it was played for ten (10) minutes. As a result, children might lost interest and motivation to memorize the verses. The issue of grabbing the children's attention, therefore, according to the researchers was pertinent when considering the use of assistive technology to memorize verses of the al Qur'an. Nevertheless, the researchers concluded that robot Nao (humanoid) had the potential to be used in the future estimating six (6) years period when Malaysia will be a developed country. Such is so since currently the device may not only assist children in memorizing verses of the al Qur'an but also able to demonstrate some basic movements of prayers for early practice and enhancement that require repetitive acts especially to young Muslims whom are still catching up in learning how to perform prayers.

Meanwhile, although the study conducted by Mustafa and Ahmad (9) concerned with interaction strategies in teaching English, the teaching approach employed by the preschool teachers in their study as in employing whole class response can be compared to the current study that employed mass recall or hafazan of selected verses of the al Qur'an. The method is feasible due to it encourages the whole preschoolers in the class to be more responsive during lessons; and therefore, is useful to be implemented in both teaching sets. With regards to the teaching and learning of English, comparison of the current findings with Lin and Johnson (10) confirm that bilingual preschoolers need immersion program to acquire the four (4) skills of English - Listening, Reading, Writing and Speaking. In the current study, assigning the preschoolers to complete their homework is one approach of immersion program or activity that can engage preschoolers in their attempt to acquire the skills. This immersion program may compensate preschoolers' deficiency in English before they start their primary schooling.

In conclusion, the findings of this study suggest that hafazan is one of the subjects that is taught in a Montessori Islamic Program similar to Kindergarten Y whilst the results pertaining to teaching and learning of English support the idea that acquiring the skills is relevant at the preschoolers'

Published By: 
early education. Findings from the current study will be of interest to parents who have the intention to send their children to aforesaid schools so the latter may benefit both knowledge of herenow and hereafter.

\section{ACKNOWLEDGMENT}

The researcher would like to thank the principle of the preschool who gave her the permission to interview the two (2) teachers in the current study. Also, thanks goes to the Ministry of Education, Malaysia who have granted the research scheme; Fundamental Research Grant Scheme (FRGS) under research ID RDU190188 to carry out the research works. Last but not least, the researcher would like to thank Universiti Malaysia Pahang (UMP) for the direct and indirect support in conducting the research.

\section{REFERENCES}

1. Bakar SA. Lebih ramai huffaz jadi profesional - Zahid: Utusan Malaysia; 2017 [cited 2019 May 1]. Available from: http://www.utusan.com.my/berita/nasional/lebihramai-huffaz-jadi-profesional-8211-zahid-1.490411.

2. Mohed MM, Ismail NA, Utaberta N, Yunos MYM, Ismail $\mathrm{S}$, Ariffin NFJAiEB. Understanding Islamic education for pre-school children in Malaysia. 2015;9(24):118-20.

3. Mohed MM, Ismail S. Islamic Education Through Nature For Pre-School Children In Selangor And Putrajaya of Malaysia. Advances in Environmental Biology. 2015;9(23):129-47.

4. Stake RE. Qualitative Research: Studying how Things Work. New York: The Guilford Press; 2010.

5. Gill P, Stewart K, Treasure E, Chadwick B. Methods of data collection in qualitative research: interviews and focus groups. Bdj. 2008;204:291.

6. DeJonckheere M, \& Vaughn, L. M. . Semistructured interviewing in primary care research: a balance of relationship and rigour. Family Medicine and Community Health. 2019;7(2):1-8.

7. Harrell MC, Bradley MA. Data collection methods. Semi-structured interviews and focus groups. Rand National Defense Research Inst santa monica ca; 2009.

8. Rugayah Hashima SFM, Hanafiah Yussof, Amily Fikri Aziz. Using Assistive Technology for Spiritual Enhancement of Brain-Impaired Children. Procedia Computer Science. 2015;76 355-9.

9. Mustafa MC, Ahmad M. Effective Interaction Strategies In Teaching And Learning of English For Preschool Children. International Journal of Academic Research in Progressive Education and Development. 2017;6(4):1340.

10. Lin L-C, Johnson C. Mandarin-English bilingual vocabulary development in an English-immersion preschool: How does it compare with monolingual development? International Journal of Bilingual. 2016;20(2):173-89.

\section{AUTHORS PROFILE}

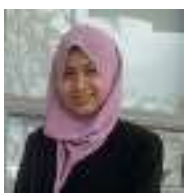

Ali, Z.; PhD is an Associate Professor at the Centre for Modern Languages \& Human Sciences (CMLHS) in Universiti Malaysia Pahang (UMP). She has co-authored several English textbooks that are used in the university. She has also contributed to writing academic papers on vocabulary learning and uses of technology in Second Language Learning at tertiary level. Her research interests include Technology-related issues on language teaching, ESL/EFL education especially with beginners in an eLearning environment, the use of new web-based learning environments to support learning and vocabulary learning among language learners.
Currently, she is embarking into a new research interest that concerns with Early Childhood Education and Financial Literacy. A trainer of English courses for adult in an outside the university, she conducted training for research courses, corporate courses; to name a few. 